\title{
COMMUNITY ACCEPTABILITY TO THE SALAFI MOVEMENT
}

\author{
Wahyu Setiawan \\ State Islamic Institute Metro \\ Iringmulyo, East Metro, Metro, Lampung, 34112 \\ E-Mail:wahyuiainmetro@gmail.com \\ Fredy Gandhi Midia \\ State Islamic Institute Metro \\ Iringmulyo, East Metro, Metro, Lampung, 34112 \\ E-Mail: fredygandhimidia@gmail.com
}

\begin{tabular}{c|c|c}
\hline Received: & Revised: & Approved: \\
10/07/2019 & $11 / 08 / 2019$ & $10 / 09 / 2019$ \\
\hline
\end{tabular}

DOI: https://doi.org/10.32332/akademika.v24i2.1819

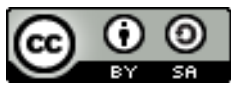

Community acceptability to the Salafi movement Licensed Under a Creative Commons Attribution-ShareAlike 4.0 International License

\begin{abstract}
The study of Salafi is generally focused on the perspective of social movements with the political opportunity structure, resources theory, and collective action frames. The three approaches to social movement theory lead to the same estuary, which is an analysis of emerging factors and the development of a social movement. Unlike the previous studies, this article focuses on the acceptance of the Islamic community's acceptability patterns to the Salafi movement. The interesting phenomenon of this movement is the so massive infiltration occurring. The community is so rapidly accepting the style and the system of sustainability offered by various Salafi groups. This article uses a sociological approach to the basis of structuralfunctional and interactionist-symbolic theories of experience in both the individual and collective levels of the followers of Salafi. Methods of collecting data through interviews, observations, and documentation with the research subject of 30 members of the Salafi group are not grass-root. The results showed that structuralist-functionally, the phenomenon of public acceptability due to the currents of modernity, shifting the concept
\end{abstract}


of the family, shifting the meaning of religious authorities, and ease of access to information technology. Symbolically-symbolic, the phenomenon is the result of individual interaction with the social environment and the search for alternative religious identity.

\section{Keywords: Salafi, Movement, and Islam}

\section{A. Introduction}

The development of Salafi with the nuance of the Arabic cultural domain, ${ }^{1}$ marked the new phenomenon in Islamic activism in Indonesia. ${ }^{2}$ The Master of Salafi infiltration is, of course, thick with the nuance of sociopolitical life surrounding it. The new order political climate change to the Reformation era in 1998 has changed the face of Indonesia to become freer especially in social behavior. Such drastic changes occur in all lines of life, including religious life. The reality is in line with Liddle's opinion that Islamists are the most prepared group to take on a new role in the current political constellations over other groups due to intense involvement in issues at the end of Suharto's reign. Moreover, the fact of changing political currents at the end of the new order powers that began to accommodate Islamic groups. ${ }^{3}$ According to Liddle, Islamic-based mass organizations such as Freedom Party (HTI), Indonesian Islamic Propagation Council

1 "Arabic cultural domain menampilkan ciri khas Islam dengan nuansa Arabisasi. Karena Jazirah Arabia memiliki banyak tradisi dan kabilah tetapi memiliki bahasa yang sama, yaitu Bahasa Arab. Azyumardi Azra mengemukakan bahwa wilayah peradaban Islam terbagi atas delapan cultural domain (sphere), yaitu: Arabic, Iranian-Persian Islam, Turkish Islam,Sudanic Islam, Indo-Pakistan Islam, Chino Islam, Western Islam, dan Nusantara Islamic cultural sphere. Azyumardi Azra, 'Materi Perkuliahan History of Southeast Asian Islam: Social Intellectual,' pada SPs. UIN Syarif Hidayatullah Jakarta pada 20 Maret 2012. Lihat juga Zakiya Darajat, 'Warisan Islam Nusantara,' Al-Turas XXI, no. 1 (2015): 6678.," 20 Maret 2012.

2 Dady Hidayat, "Gerakan Dakwah Salafi Di Indonesia Pada Era Reformasi," MASYARAKAT: Jurnal Sosiologi 17, no. no.2 (2012): 115-16.

3 "Howell memotret transformasi pemikiran keagamaan di Indonesia pasca Orde Baru pada saat mengkaji tiga aliran keagamaan: Salamullah, Brahma Kumaris, dan Anand Ashram. Ia menunjukkan adanya trend kebebasan pemikiran keagamaan terutama yang ditampilkan oleh masyarakat kelas menengah perkotaan yang mengembangkan sikap toleransi tinggi terhadap berbagai praktek keberagamaan masyarakat di Indonesa. Lebih lanjut baca Julia D. Howell, 'Muslims, the New Age and Marginal Religions in Indonesia: Changing Meanings of Religious Pluralism,' Social Compass 52, no. 4 (2005): 473-93. Lihat juga Dady Hidayat, "Gerakan Dakwah, 122," t.t. 
(DDII), Warriors Jihad, and Islamic Defenders Front (FPI) have great political resources after Suharto's decline. This analysis is based on other top facts that they have an alliance and access to the politicians also supported by the organization and the media. ${ }^{4}$

Salafi Da'wah Movement in Indonesia, when seen through social movement theory, is shown to be surrounded by various factors that are intertwined and interconnected. Therefore, the political system openness factor but also supported by the packing of values and ideology. This process is called framing. The frame serves to establish meaning and interpretation of certain events or conditions. This process aims to mobilize potential and get support from various parties. ${ }^{5}$ As well as the support of resources from Middle Eastern countries. According to Hasan, Salafi's Da'wah movement in Indonesia cannot be separated from Saudi Arabia's highly ambitious global campaign encouraging the process of Arabization of the Islamic world. ${ }^{6}$

Previous research on the Salafi movement generally focused on the theological aspects and understanding Salafi itself. Likewise, Salafi's movement related to the emergence of religious radicalism and its development in Indonesia. Salafi is seen as one of the collective movements that are confronted with existing authorities, both in the institutional authority covering the political and state areas as well as the cultural authority such as the belief system, religion, or practice of the Trust. ${ }^{7}$

4 R. William Liddle, Improving the Quality of Democracy in Indonesia: Toward a Theory of Action," Indonesia 96, 2013, 59-80.

5 Benford, Robert D, dan David A. Snow, Framing Processes and Social Movements: An Overview and Assessment., vol. Annual Review of Sociology 26, 2000, 611-39 Lebih lanjut bahwa proses framming, ada tiga tahapan yang meligkupi, yaitu diagnostic framing, prognostic framing dan motivational framing. ketiga tahapan itulah yang disebut sebagai core framing task.

${ }^{6}$ Hasan dan Noorhaidi, Laskar Jihad: Islam, Militancy, and the Quest for Identity in Post-New Order Indonesia. (New York: SEAP, 2006), 32 tesis yang sama diutarakan Anjar Wehler-Schoeck dalam kata Pengantar buku ; Mohammad Abu Rumman, I am a Salafi: a Study of the Actual and Imagined Identities of Salafi (Amman: FES, 2014) begitu juga buku yang ditulis Noorhaidi Hasan, Laskar Jihad yang merupakan disertasi di Universitas Leiden Belanda.

7 "Pendekatan yang sering digunakan adalah political opportunity structure (struktur kesempatan politik), resources mobilization theory (teori mobilisasi sumber daya), maupun collective action frames (kerangka aksi kolektif). Di antara penelitian serius tentang gerakan dakwah Salafi adalah karya Muhammad Belanawane, 'Agama, Kebudayaan, Dan Kekuasaan: Catatan Teoritik Dari Seorang Salafi,' Antropologi Indonesia 32, no. 2 (2011): 82-98. Begitu juga buku yang ditulis 
Different from previous research, this article focuses on very fast reception by the community, especially those in Metro city, Lampung against the Salafi movement. The phenomenon of ' salafisation' is examined considering the Metro city is originally the purpose of the colonization program which is part of the ethical-political application of Van Deventer. As an ' artificial ' region, the Metro is composed of open social structures. From the point of development of religious understanding, the Metro community became very inclusive in the acceptance of a diversity pattern of sustainability. Despite the majority of the population of ethnic Javanese, the pattern of religious tradition differs from the pattern of the traditional Javanese countryside. Salafi elections in the massively as a manifestation of the religious experience of course through the process both at the individual level and collective society. Therefore, the problem of this research can be identified in the question of how is the experience of the famous in the process of establishing religious identity in the Salafi group as a cultural capital in social interaction?. The process has committed efforts in the construction of identities of previous religious traditions to Salafi religious practices, especially at the bottom level (grass-root). Likewise, the factors influencing the form of the identity manifestation that has been constructed, and the efforts of preserving identity both in the internal and external areas.

\section{B. Identitas dalam Wacana Kelompok Keagamaan}

Identity is a source of meaning and human experience. A discrete construction that changes its meaning according to space, time, and usage. ${ }^{8}$ Thus, identity is the result of social construction. Identity touches much social life from relatively stable characteristics such as religion, race, ethnicity, and nationality, to certain more flexible processes and events such as migration, assimilation, and travel history individually as well as Communal. ${ }^{9}$ In other words, identity is not something that is established and doomed but rather the meaning that is formed with consciousness

Noorhaidi Hasan, Laskar Jihad yang merupakan disertasi di Universitas Leiden Belanda.

${ }^{8}$ Chris Baker, Cultural Studies: Teori Dan Praktek (Yogyakarta: Kreasi Wacana, 2005), 171.

9 Michael A. Hogg, Social Identifications, Social Identifications (London: Routledge, 2006), 75. 
through a social process. This is why identity is a compound. Identity can be self-representation or social action. ${ }^{10}$

Koentjaraningrat sees identity in an anthropological perspective as "an awareness of the distinctive nature of oneself, his own, the community itself, or the country itself."11 Each individual will then seek to display his or her identity to show similarities or differences in the existing social community, including in a pattern of branding. The identity is closely related to the sense of belonging that implicates the personal sense of the location and position of self as well as a stable core for every human individuality. ${ }^{12}$ It appears that the concept of identity rests on the self, which explains what and who that person is in an attempt to determine a position in the community. This understanding is reinforced by Hogg and Abrams who stated that the identity is "... People's concepts of who they are, of what sort of people they are, and how they relate to others (whether members of the same group - in-group - or of different groups - out-group), is largely determined by the groups to which they feel they belong." 13

The reality of the program can be seen in the conception of religious group identity. The process is formed by mutual influence and reciprocation between individuals and communities to show differences with groups outside themselves. The establishment of group identity is derived from interactions between individuals bearing the term social identity in a sociology study.

When it is associated with groups in Islam, social identity is a group of people who are shared with different patterns. Social identities contain value as well as emotions that are perceived to be identical in each individual as part of a social group. Thus, social identity is generally a sign of an individual or personal identity. Regarding social identity, Eriksen defined it as something that "Has" to do with which groups a person

10 Castells dan Manuel, "Castells, Manuel. The Information Age: Economy, Society and Culture, Vol. 2: . Contemporary Sociology. 2nd ed. , 2010.," The Power of Identity Contemporary Sociology, Chicester: Wiley-Blackwell, Vol. 2, no. 2nd ed (2010) 3.

11 Koentjaraningrat, Pengantar Ilmu Antropologi. (Jakarta: Rineka Cipta, 1990), 84.

12 T. J. Lan, Susahnya Jadi Orang Tionghoa: Ke-Tionghoa-an Sebagai Konstruksi Sosial," dalam Harga Yang Harus Dibayar. Sketsa Pergulatan Etnis Tionghoa Di Indonesia, 1st ed (Jakarta: Gramedia Pustaka Utama dan Pusat Studi Tionghoa, 2000), 7 .

${ }^{13}$ Michael A. Hogg, Social Identifications, Social Identifications, 2. 
belongs to, who he or she identifies with, how people establish and maintain invisibly but socially effects boundaries between us and them. ${ }^{14}$ "In general, social identity in religious groups refers to personal identification as one of the members of the community about the higher social sphere in the form of an attempt to incorporate themselves into various religious groups. 15

The identity of the religious group is thus the use of some aspects of a group's background to separate them from others. Individuals in certain religious groups are always trying to identify themselves as belonging to the same religious group's category. Thus, the social identity at the next level spawned a categorization of the social world in-group and outgroup. ${ }^{16}$ The identity of the religious group is a process formed through the interpretation of physical and social reality as having the same religious attributes. As well as individual efforts in conducting the generalization of identity. Religious group identities develop through the internalization of self-enrichment (self-typification) by other people who are considered important (significant others), about who I am and who others based on their religious groups.

Castells argues that identity construction occurs if there is an individualization process by the social structure associated with local and global conditions. Individualization of social structures is done through the construction of meanings in the process of internalization value. The process leads to the establishment of a collective identity. While according to Berger and Luckman, the internalization process in the construction of collective identities is preceded by two other processes, namely externalization, and objectivity. ${ }^{17}$

The dialectics between externalization, objectivity, and internalization are the demands of processes occurring in society, including religious groups. The three processes are continuous and inseparable. Through these three processes, the community can be seen as objectively and subjective. The fact that the collective identity is a set of individual identity, Burke and Stets conduct the specification of a study related to the identity scheme

14 Eriksen, T.H, What Is Anthropology? London: Pluto Press, 2004 (London: Pluto Press, 2004), 156-57.

15 Adam Kuper dan Kuper Jessica, The Social Science Encyclopedia, , 2nd ed (London: Routledge, 2005), 1356-57.

16 Brewer M.B, "Taking the Social Origins of Human Nature Seriously: Toward a More Imperalist Social Psychology," Personality and Social Psychology Review 8, no. no.2 (2004): 107-8.

17 Peter L. Berger dan Thomas Luckman, Tafsir Sosial Atas Kenyataan: Risalah Tentang Kenyataan Sosiologi Pengetahuan (Jakarta: LP3ES, 1995), 87. 
focused on the individual identity. Through the base of the interactionistsymbolic theory, he stated that social agents and social structures were the dominant factors in the formation of individual identities (personal). Especially agents or actors and structures that strongly affect the individual. ${ }^{18}$ The collective identity is a person's identity.

The reciprocal relationship between identity and the externalization, objectivity, and internalization was reinforced by Côté's outspoken in psychoanalysis as pioneers of identity theory as Erickson developed. This theory departs from the central point of the self-concept built by Freud. Côté's theoretical efforts continued with the concept of synthesis between psychoanalysis and social psychology. Côté's theories of identity formation, agency, and culture are based on the mutual relationship between social culture, interaction, and personality. In the relationship, there are three dominant aspects, namely the third externalization process, objectivity, and internalization. Reciprocal between identity formation, agency, and culture also displays in its presentation of self as well as the social construction of reality. ${ }^{19}$ The theorist on the identity of the construct can be described as follows

The influence of the social structure of the interaction process between individuals, of course, involves socialization and social control. Daily interactions with other individuals lead to the internalization of norms and values of social structures that will give birth to personal identity. At the end of the knot, this individual identity is used in interactions with others, both in its community and with parties outside of its community. Through such repeated processes, social structures are maintained or altered, interactions that occur normally or are disrupted, and individuals are formed to have a transformation.

Researchers use identity theory with an interaction-symbolic base and structural-functionally researchers use in viewing the process of public acceptability to the Salafi movement. Individuals and groups are viewed from the narrative side of self and its group based on the identity of groups formed or formed

18 Peter J. Burke dan Jan E. Stets, Identity Theory, Journal of Chemical Information and Modeling, vol. 53 (New York: Oxford University Press, 2009), 6-13.

${ }^{19}$ James E. Côté dan Charles G. Levine, Identity Formation, Agency, and Culture, Journal of Chemical Information and Modeling, vol. 53 (New Jersey: Lawrence Erlbaum Associates, 2002), 7-8. 


\section{Research Methods}

This research is seen from its location including field research with a qualitative descriptive model that implemented with a case study in Metro City, Lampung. Qualitative Data is collected with unstructured interview techniques (open-ended interviews), observations, and documentation. The primary data is obtained directly from the 30 speakers set purpose which is specific to the ordinary members who do not belong to the SALAFI Study Group. The "grass-roots" selection of the Salafi group is intended to find deeper into the motive of the acceptability to Salafi Da'wah. In addition to the Study Group, the Metro society in general that displays the style of Salafi is used as the main informant of this research.

Data analysis uses a sociological approach to focus on interactionistsymbolic and functional-structuralist. Data analysis through cycle-shaped processes of three stages that take place repeatedly: expanding the exploration stage, focused exploration and checking or confirming research findings. The increase in the credibility of qualitative research conducted by researchers by prolonged the involvement of researchers in the context and background of the research, namely in the area of the Salafi movement pockets. The act of prolonged involvement was carried out in addition to the efforts to build a network and trust with the subject of research, as well as to understand more about the culture, habits, and behaviors of the Salafi group in the research site. ${ }^{20}$

\section{Metro City: Structure and Social System Review}

Metro city has historically as a small city since the Dutch era. In the Dutch era, Metro was still a wilderness as part of the Marga Nuban region, which was later opened by the colonists (a term designation for people who first opened land) in 1936. The colonization program, encouraged by the Dutch government, is a program of transmigration by bringing the inhabitants of the island of Java to the island of Sumatera. This program relates to the policy of the colonial government by implementing ethical politics at the beginning of the 20th century, including encouraging colonization programs.

20 John W. Creswell, Research Design: Qualitative, Quantitative, and Mixed Methods ApproachesTitle (California: Sage Publications Inc, 2003), 184. 
The former city destination of colonization, the population of Metro are dominated by migrants from outside Lampung, the largest are ethnic Javanese, Sundanese, and Balinese. The longer, the inhabitants of the city are increasingly coming from the inside and outside Lampung, such as Palembang, Minang, Batak, Chinese, and other tribes. However, Javanese nuance still feels thick. It is seen in the name of several villages or residential areas that are the same as the villages on the island of Java. for example Bantul region, according to its history most of the inhabitants of the area are from the Bantul area in Yogyakarta. Likewise, Pekalongan, Purwoasri, Purwosari, etc.

The population of Metro city is concentrated in central Metro district as the city center and West Metro district. This concentration is increasingly reduced to the periphery areas especially the northern and southern regions. While the East Metro Sub-district has the characteristics of ' Antara ', from the population density is also a heterogeneous composition of its society. In a demographic, East Metro represents the diversity of Metro city. Therefore, to deepen the analysis of the structure and social system of the people of Metro city is more directed to the East Metro area with concentrations in two villages, Iringmulyo and Tejosari as representations of Metro ' urban ' and Metro ' Rural '.

The second name of the village shows the majority of the population dominated by Javanese people. The Javanese domination influenced the colloquial language used by Tejosari society, which is Javanese in addition to Bahasa Indonesia. There is also some very strong Javanese culture as a reflection of maintaining and protect its identity as a descendant of Java, such as the tradition of Slametan, Wayang, Jaranan, Sintering, and the naming of their children with names Typical Javanese. Although for the area Iringmulyo this tradition gradually began to fade.

Javanese cultural culture has a strong influence on the social system in Tejosari village. With the characteristic of the Javanese rural community that relies on agriculture, the kinship pattern that formed is not different from the atmosphere of rural living (village-based family) characterized by the extended family system (spacious family ). It is evidenced that as much as $64 \%$ of the speakers declare after marriage they live in their own homes, and as many as $36 \%$ declare life along with parents. Although $64 \%$ of them live in their own homes, based on researchers ' observations, most choose locations around parent and group dwellings. In everyday life among the core, family involved many interactions that elicit strong social control. 
The formed social system then demonstrates a relatively uniform pattern of life with a high level of integration among the various groups in which individuals participate and interact. Kinship bonds in the family remain strong and functional. From this, it is apparent that the perils with traditional patterns persist from the insisting of urban influences. Strong traditional patterns make large family functions are instrumental in the control of the life of a family.

Although the family system remains in the extended family pattern, various social phenomena such as modernization and economic developments continue to affect traditional kinship patterns. The evidence of such reality can be modeled by the widespread values of individual freedoms such as freedom of finding mate, persistence in the welfare of individuals, and less concerned with the continuity and greatness of the wider family name Which is characteristic of the conjugal family system. However, different from the system of conjugal family Ansich, in the life of Community Tejosari Village does not happen disconnect of the relationship in the system of a large family that has been built hereditary in traditional family life. In other words, the kinship system formed is a non-detached social life Unit (unemancipated) from the bonds of broad relatives, but individually free to move following the individual will and become a more Specializes.

So, the family structure that formed the result of modern life adaptation directing the family system in Kelurahan Tejosari took the form of an "extended family that has been adjusted". That is the wide family type that changed from traditional spacious family type. In this type of family, the characteristic of the conjugated family is like not knowing the leadership of the authority, husband and wife involved in the intimate personal relationship, between parents and children there are not authoritarian relationships, the number of children in the family to be small, And the youth married in a not too young age (they needed a long enough learning process). However, there is still an interactive-social connection with other members which is characteristic of extended family.

Unlike the village Iringmulyo, although Javanese culture is still relatively thick with the characteristics of a semi-urban society, the community order has led to the pattern of family Konjugal (conjugal family). However, it is not denied the pattern of the extended family that still appears in the indigenous Iringmulyo (the son of the colonists/people who first opened the land of Iringmulyo). Iringmulyo's indigenous peoples still uphold the traditional values of extended family, such as decisionmaking, centralized division of role-making, and kinship bonds with large families still very strong. 
Interesting phenomena occur in the immigrant community. As a majority group of Iringmulyo communities, they have factually separated from their families. Family independence was formed by reforming a new family dependency on the original family. Although for the precarious issues related to the interests of the large family, deliberations remain an option in completing them. But in general, individuals in this migrant society are more able to choose and determine their choice freely without any big family intervention.

So, for the area of Iringmulyo, the pattern of society has been led to the family of Konjugal, but not purely conjugal. This family structure can be referred to as a quasi-conjugal family. Because however the traditional culture that they inherited from the predecessor, is not totally disappearing from society. Interactive-Social relationships with extended family members are still maintained. But the traits of the Conjugal family are realized in their daily life.

The social system with the structure of the family will affect the individual community in practice and patterns of diversity. The historicity of religion entrusted the relationship between religious interaction with humans and vice versa. The structures and specific social systems in which individuals interact in them will influence the choice of religious practices to be chosen.

\section{E. Individual religious experiences of Salafi: structural-functional and interactionist-symbolic study}

A description of the social and cultural evolution in the community of the Metro city in the form of religious life in the last two decades, if viewed from the thesis proposed by Nurcholish Madjid is one of the effects of modernity. Modernity has become a separate problem in the culture of preindustrial society. In it occurs various contradictions that run in a rhythm of change in the cultural dimension and human consciousness. In this position, each person is tendencies to his or her prior sign values or building a defensive mechanism by carrying a fundamental value that is very human. Usually, the alternative counterparty to modernization is chosen religious values. This situation eventually gave birth to a new kind of consciousness in religion, which everyone can express differently and vigorously.

It is apparent that the rapid flow of modernity shakes the cultural joints of a society, the tendency to return to the primordial values is also increasingly stronger. The influence of modernity also affects the social 
structure of society, including the people of Metro city. The following descriptions show the influence of modernity from a structural-functional standpoint focused on changing family structures, shifting religious authorities, and the media massif of public acceptability to movements Salafi.

1. Change of family structure

... Yes, it is ... The family also initially refused... But. If we practice deed, it is clear from the Sahih Hadith... Yes, do it. supposed that words of ustad that I remember and it strengthens me. A year, two years, as long as you accumulate reward... people will tired... All at first must be so. The other friends are also so fell the same. Afraid to practice something. But yes it is, Dita'lim, forged, Ta'lim, forge again. Original beliefs have a strong foundation that is already practiced..$^{21}$

The narrative shows the development of the Salafi movement in the community because the group's position can replace the family function for its followers. The presence of a "new family" community can be greatly coveted by its members, especially when they experience social alienation due to the urbanization process and get in touch with the original family. Alfin Tofler called this symptom with a cultural shock, a cultural shock that unwittingly dragged him into an unrecognized new cultural. To function as a family community, the number of group members is usually small, so they can know each other. The condition of alienation can also arise because of the change of the family structure that originally was more oriented to the joint family or extended family as a characteristic of traditional society towards the nuclear family, a family structure consisting only of main families. This family form presents self-reliance and reduced control of extended family function.

On the one hand, this last family form gives freedom of choice in every aspect of life without the extensive family intervention included in the choice of a diversity pattern. On the other hand, when they choose to become a Salafi, alienation occurs from a large family which is opposite and looks cynical to individual choices. In this condition, the presence of the Salafi group is a new community that is not based on blood kinship but based on relationships and diversity emotion. ${ }^{22}$ 2018.

21 “Wawancara dengan Soleh (bukan nama sebenarnya) tanggal 11 Agustus

22 "Wawancara dengan Abdullah (bukan nama sebenarnya) tanggal 15 Juli 2018. 
The role of ustadh and the congregation in the Salafi community are instrumental in the effort to deal with conflicts in the workplace, society, and family in social interactions performed by individuals. Especially for individuals who are in phases or early stages of immigration. The Salafi community that regularly implements Ta'lim serves as a "new family." In sociological conception, it can be referred to as a joint family with a diversity of patterns. The Salafi community makes them feel secure and protected. The existence of this new joint family form makes the individual feel at home.

\section{F. Shifting religious authority}

The shifting of religious authorities amid society can be seen in two aspects, namely: first, the model of religious approaches in society; And secondly, the shift of holders of religious authorities. Here outlined both forms of shifting the religious authority

There is a tremendous development on the global level with the presence of various Islamic groups. In the context of Indonesia, especially after the Reformation in 1998 emerged new Islamist organizations and groups, the Islamic Defenders Front (FPI), the Warriors Jihad, Hizbut Tahrir and the Indonesian Mujahidin Council (MMI) which is outside the largest Muslim organization Muhammadiyah and NU. The presence of these groups also affects the viewpoint and study of Islam that has been present. There is a paradigm change in the method of reviewing Islamic law from the Fiqhī paradigm towards the Manhaji paradigm that requires the study of Islamic law based on the understanding of naș directly. This change is a necessity in the reality of Islamic law.

In the Fiqhi paradigm, the Fiqh Learning (Islamic law) generally does not explicitly display the support of Naș. The transmission Model of religious sciences, especially in the field of Islamic law, further emphasizes the product of Islamic law that has incarnated as a closed corpus in the Fiqh conception. The exposure of various provisions in Islam is not accompanied by the inclusion of detailed verse. This is one characteristic of the writing of various works of fiqh from medieval times. Especially when it has entered a more specific space in the scope of Islam Nusantara. This reality is understandable that a legal provision is often the result of the inferential-inductive reasoning of a legal expert on the various verses and hadith that is absorbed. It means that a legal provision of either lawful, unlawful, mandatory, Sunnah, or Mut change is not only based on one verse or hadith. When included only one or more verses is feared the 
simplification or distortion of the conclusion taken by an Islamic legal expert.

While the Manhaji paradigm directs the Fiqh study in the form of a study that demands that all the legal conclusions that can be practiced should be known to have explicit support naș. This paradigm emphasizes the most authentic sources of Islam (the Qur'an, the Sunnah of the prophet and the traditions of the early Muslim generations, the Salaf). They strictly select everything that comes from outside parties and stick firmly to what is mentioned in the religious text. The concept of law developed is a form of prohibition on anything and anyone who is not following the literal instruction of revelation. People who make new laws in religion without the basis of revelation or Hadith of the prophet. This means to have made his sharia in religion. so, it has been deplorable and forbidden. The aspiration of such a mindset brings to the axiom that the person who makes the new law in religion without the basis of revelation or hadith the Prophet saw. Explicitly means they have made the sharia in religious.

The Salafi group in various studies, which is performed as an individual for the society. Moreover, Ta'lim form is always based on various direct evidence that makes the community feel satisfied and confident with the understanding offered by the Salafi group. This reality is as spoken by the following informant:

The most effective until I set the heart in Salafi when there is a huge tabligh in the mosque qowi... Eh, not... Nurul Huda Mosque when Ustadz Subhan Bawazir from Bogor or Jakarta... used to be often established there... Now the roving is not must be there. If you used to often there. there is no routine agenda for tabligh Akbar, but Ta'lim routine. They are in Ta'lim in the delivery of full evidence... It means this opinion according to the religious scholar, the evidence is...that's what I can not accept before. ${ }^{23}$

In line with the statement, the other informant explained the following:

Salafi is so different... During this time I participated in Muhammadiyah, or other studies at a certain celebration, different... when ta'lim... It may the ustadh convey goodly, so it means if we compare with the Muhammadiyah, far. This is where I live... Not in Ma'had ' Ali, if in Ma'had ' Ali already tends to be good... Most usually textbook, read, study (Muhammadiyah), all the complete verse. If in Muhammadiyah it is minimal evidence. The number of Tarjih is... then I get hidayah to istiqamah here. ${ }^{24}$

Public acceptability to the Salafi movement is also closely related to the religious social structure that exists within the community of the predominantly Javanese Metro city. The characteristic of traditional rural

23 "Wawancara dengan Adi (bukan nama sebenarnya) tanggal 15 Juli 2018.

24 "Wawancara dengan Cipto (bukan nama sebenarnya) tanggal 15 Juli 2018. 
communities, especially in Javanese culture, is dominated by a religious elite group. This religious elite often serves to control the religious system. The way that is taken is by the principle of taking good and refusing that is considered destructive or contrary to the religious understanding that has been established in the community. Besides, the religious elite represented by the figure "Kiai" also mastered the framework of the Islamic scientific structure. This role is what Clifford Geertz referred to as a cultural broker, which is to do the parochialism of universal values and universalization of local values. ${ }^{25}$ While in rural communities such as the East Metro Tejosari, the role of the religious elite who do the selection process accept and reject (change and continuity process) does not happen. Kiai's role is taken over by Salafi's ustadh who politically and continuously filled the void of religious social roles. A speaker says the following.

there are many regular studies... If you want to go around, every week... Every night there is... tonight the Wednesday night at the Ganjar Agung in the mosque behind the house that has a Jodo pharmacy... Before the red light to the right of the road. Thursday night in (Masjid) Muthmainnah, Chandra Mart enters before the big Way out, to the right...... The average who participated in a range of 50 people... The congregation from salafi's people if already know his brother or who ya participated too... If Night is Saturday, in Ganjar Agung again.... if I do a minimum routine yes that is in the hut, the Friday night... Ustadh that often talk on Ta'lim Ustadz Salman of the Lodge... There is some ustad that goes out, about four... some ustadh in the boarding school are all migrants. ${ }^{26}$

\section{G. Ease of access to information technology}

The Salafi movement of the group appears massively widespread access to technology and information developments. The ease of access to social media increasingly facilitates the delivery of a carried ideology. Moreover, the Salafi group Taḥkīmussunnah Al-Islāmī, social media became the public means for the dissemination and access to ta'lim. Tahkimussunnah is even able to build boarding schools in the area of Punggur, central Lampung. However, for religious propaganda, more concentrated in the Metro area. For the wider reach of Da'wah, social media use in the form of Facebook account Matsil (Ma'had Tahkimussunnah AlIslami and Hijrah TV. The following profiles of the two social media accounts of the Salafi Tahkimussunnah Al-Islami Group

25 "Istilah ini diperkenalkan oleh Eric Wolf dan dikembangkan oleh Clifford Geertz dalam 'The Javanese Kijaji: The Changing Role of Cultural Broker,' Comparative Studies on Society and History, vol. 2, 1059-1960, hlm. 229," t.t.

26 "Wawancara dengan Abdullah (bukan nama sebenarnya) tanggal 15 Juli 2018. 
As well as the transfer of religious knowledge through printed media in the form of popular Islamic books. These books are generally the translation of the work of the Middle East scholars who have a different tradition of religious thought with Muslim Nusantara. People who are ' confused ' with his religious identity will turn to books that carry the spirit of the Islamic. Without a culture of criticism of a book or over the Internet, the existing religious information is received ' so ' as a truth.

In addition to changes in family structures, shifting religious authorities, and the ease of access to media, the public acceptability of the Metro to the Salafi movement can also be seen from the interactionistsymbolic side. The meaning is that the experience of individualized and individual spirituality is not merely influenced by changes in social structures, but also as a result of individual interactions with the underlying environment. It includes the process of internalizing the value that is in the individual's loneliness

Judging from the point of view interactionist-symbolic, there are common traits in the members of this group are those who are religiouslyinclined. That means they are already inclined to religious but confused in channeling religious desires. There are a few things that do this, among them, because of the poor background of religious knowledge. So, usually, the one who later migrated into the Salafi group is the people who tend to be very religious but do not get satisfactory answers to the problems of life that he faced. ${ }^{27}$ The rise of various forum studies by promoting Salafi theology is very neat to make the interest and tendency of a society increasingly greater than this group. From the results of this study reveres to return to Islamic teachings, namely the Qur'an and Hadith to be an intrinsic motivation of the individual to deepen Islam further. ${ }^{28}$

Acceptance to new understanding as a result of typical people who already tend to be religious but experiencing confused to understand their religion. So that all the teachings conveyed during the support of Naș will be immediately accepted. Therefore, when a great curiosity to the religion is filled by a religious understanding with revered to the Qur'an and Hadith, which they understand as the most authentic religious source, it is immediately accepted their thoughts pattern. ${ }^{29}$ 2018.

27 “Wawancara dengan Habib (bukan nama sebenarnya) tanggal 17 September 2018.

28 "Wawancara dengan Indra (bukan nama sebenarnya), tanggal 11 Agustus

29 "Wawancara dengan Rizki (bukan nama sebenarnya) pada tanggal 17 September 2018," t.t. 
Regarding the phenomenon of large religious tendencies, public acceptability to the Salafi group is also a form of criticism of the established religious model. In some societies, practice is more emphasized on the traditions that have lived in a society. When the religious practice has become a tradition, that is proof of authenticity so that it is judged to have roots in religion. The Salafi group has a distinctive characteristic of the methodological foundation which commits the mindset that rests on the text. Legal excavation attempts should return directly to the sound of a verse or hadith with a textual-literalistic approach or see the meaning of the Zahir emerging from the text. This model's approach treats textual Qur'an as a reference in understanding the messages contained in the text

Therefore, the Salafi community has members of diverse religious organizations. A resource formerly affiliated with Muhammadiyah says the following

Yes... The former is Denger anyway, meanwhile... That time is still in Muhammadiyah. Still a sympathizer, not an administrator. initially heard Salafi is strict, there are many prohibitions... At that time still often mocking... Then the brother of wife Time had Ngaji there... In Tahkimussunnah. Keep chatting with him. It is figh much closer to Muhammadiyah. Knowing the difference with Muhammadiyah is the Idul Fitri time. If it is here, obey to Ulil Amri It is a mandatory thing, the Muhammadiyah remained with the Tarjih council. 30

The Salafi group in this study led to the movement of the Salafi Da'wah. Therefore, there is moderate which not anti-government, with notes as long as the government does not command anything contrary to the teachings of Islam which are understood. The narrative above shows the tendency towards Salafi's understanding as a critique of one religious organization that is often opposite to the government in the determination of the beginning Ramadan and Idul Fitri.

Packaging and planting values that are done gradual and structured in the form of Ta'līm become the attraction of people to do Hijrah in this group. Salafi's taught became an oasis of concern amid a conflict of religious interpretations often appearing in the community between established religious organizations. Salafi offers a friendly model and pattern of Da'wah with the verse that is expressed rationally and completely. Every question from Jama'ah answered plainly with detailed verse. Minimize the difference (ikhtilāf) that occurs. ${ }^{31}$

30 "Wawancara dengan Rizki (bukan nama sebenarnya) pada tanggal 17 September 2018."

31 "Wawancara dengan Habib (bukan nama sebenarnya) tanggal 17 September 2018. 


\section{H. Conclusion}

Public acceptability to the Salafi group of religious identity formation models can be identified through the structuralist-the functional and interrogative-symbolical approaches. Structuralist-Functionally, the phenomenon is caused by: first, a modernization process that creates a tendency if returning to primordial values; second, shifting the concept of the family from the extended family model to the nuclear family that forms a joint family relationship based on religious sentiments; third, the transition of meaning of religious authority in the form of shifting model of religious approach and the meaning of actors of religious authority; and fourth, ease of access to information technology in the spread of Da'wah Salafi. Interactionist-Symbolically, acceptance of Salafi due to individual interaction and search of alternative religious identity. From the angle of the members, there is a common feature of people who are religiously inclined. The Salafi group grew rapidly because the group's position was able to replace family functions for its members.

Finally, the strong tendency of society against religious aspects should be welcomed through an improved introduction of a friendly and contextual religious approach. It takes maximum effort from various elements of religious elites in both the religious and individual bases to re"embrace" the community in the religious framing of the Rahmatan Lil ' Alamin. As well as strengthening the role, function, and control of the family amid structural changes and social systems due to modernization [.]

\section{REFERENCES}

Adam Kuper, dan Kuper Jessica. The Social Science Encyclopedia, ,. 2nd ed. Routledge vol. London: Routledge, 2005.

"Arabic cultural domain menampilkan ciri khas Islam dengan nuansa Arabisasi. Karena Jazirah Arabia memiliki banyak tradisi dan kabilah tetapi memiliki bahasa yang sama, yaitu Bahasa Arab. Azyumardi Azra mengemukakan bahwa wilayah peradaban Islam terbagi atas delapan cultural domain (sphere), yaitu: Arabic, Iranian-Persian Islam, Turkish Islam,Sudanic Islam, Indo-Pakistan Islam, Chino Islam, Western Islam, dan Nusantara Islamic cultural sphere. Azyumardi Azra, 'Materi Perkuliahan History of Southeast Asian Islam: Social Intellectual,' pada SPs. UIN Syarif Hidayatullah Jakarta pada 20 Maret 2012. Lihat juga Zakiya Darajat, 'Warisan Islam Nusantara,' Al-Turas XXI, no. 1 (2015): 66-78.," 20 Maret 2012. 
Benford, Robert D, dan David A. Snow. Framing Processes and Social Movements: An Overview and Assessment. Vol. Annual Review of Sociology 26, 2000.

Brewer M.B. "Taking the Social Origins of Human Nature Seriously: Toward a More Imperalist Social Psychology." Personality and Social Psychology Review 8, no. no.2 (2004): 107-13.

Castells, dan Manuel. "Castells, Manuel. The Information Age: Economy, Society and Culture, Vol. 2: . Contemporary Sociology. 2nd ed. , 2010." The Power of Identity Contemporary Sociology, Chicester: Wiley-Blackwell, Vol. 2, no. 2nd ed (2010). https:// doi.org/10.2307/2654791.

Chris Baker. Cultural Studies: Teori Dan Praktek. Yogyakarta: Kreasi Wacana, 2005.

Dady Hidayat. "Gerakan Dakwah Salafi Di Indonesia Pada Era Reformasi." MASYARAKAT: Jurnal Sosiologi 17, no. no.2 (2012): 115-16.

Eriksen, T.H. What Is Anthropology? London: Pluto Press, 2004. London: Pluto Press, 2004.

Hasan, dan Noorhaidi. Laskar Jihad: Islam, Militancy, and the Quest for Identity in Post-New Order Indonesia. New York: SEAP, 2006.

"Howell memotret transformasi pemikiran keagamaan di Indonesia pasca Orde Baru pada saat mengkaji tiga aliran keagamaan: Salamullah, Brahma Kumaris, dan Anand Ashram. Ia menunjukkan adanya trend kebebasan pemikiran keagamaan terutama yang ditampilkan oleh masyarakat kelas menengah perkotaan yang mengembangkan sikap toleransi tinggi terhadap berbagai praktek keberagamaan masyarakat di Indonesa. Lebih lanjut baca Julia D. Howell, 'Muslims, the New Age and Marginal Religions in Indonesia: Changing Meanings of Religious Pluralism,' Social Compass 52, no. 4 (2005): 473-93. Lihat juga Dady Hidayat, "Gerakan Dakwah, 122," t.t.

"Istilah ini diperkenalkan oleh Eric Wolf dan dikembangkan oleh Clifford Geertz dalam 'The Javanese Kijaji: The Changing Role of Cultural Broker,' Comparative Studies on Society and History, vol. 2, 1059-1960, hlm. 229," t.t.

James E. Côté, dan Charles G. Levine. Identity Formation, Agency, and Culture, Journal of Chemical Information and Modeling,. Vol. 53. New Jersey: Lawrence Erlbaum Associates, 2002.

John W. Creswell. Research Design: Qualitative, Quantitative, and Mixed Methods ApproachesTitle. California: Sage Publications Inc, 2003.

Koentjaraningrat. Pengantar Ilmu Antropologi. Jakarta: Rineka Cipta, 1990.

Michael A. Hogg. Social Identifications, Social Identifications. London: Routledge, 2006. 
Mohammad Abu Rumman. I am a Salafi: a Study of the Actual and Imagined Identities of Salafi. Amman: FES, 2014.

"Pendekatan yang sering digunakan adalah political opportunity structure (struktur kesempatan politik), resources mobilization theory (teori mobilisasi sumber daya), maupun collective action frames (kerangka aksi kolektif). Di antara penelitian serius tentang gerakan dakwah Salafi adalah karya Muhammad Belanawane, 'Agama, Kebudayaan, Dan Kekuasaan: Catatan Teoritik Dari Seorang Salafi,' Antropologi Indonesia 32, no. 2 (2011): 82-98. Begitu juga buku yang ditulis Noorhaidi Hasan, Laskar Jihad yang merupakan disertasi di Universitas Leiden Belanda," t.t.

Peter J. Burke, dan Jan E. Stets. Identity Theory, Journal of Chemical Information and Modeling,. Vol. 53. New York: Oxford University Press, 2009.

Peter L. Berger, dan Thomas Luckman. Tafsir Sosial Atas Kenyataan: Risalah Tentang Kenyataan Sosiologi Pengetahuan. Jakarta: LP3ES, 1995.

R. William Liddle. Improving the Quality of Democracy in Indonesia: Toward a Theory of Action," Indonesia 96, 2013.

T. J. Lan. Susahnya Jadi Orang Tionghoa: Ke-Tionghoa-an Sebagai Konstruksi Sosial," dalam Harga Yang Harus Dibayar. Sketsa Pergulatan Etnis Tionghoa Di Indonesia. 1st ed. Jakarta: Gramedia Pustaka Utama dan Pusat Studi Tionghoa, 2000.

"Wawancara dengan Abdullah (bukan nama sebenarnya) tanggal 15 Juli 2018," t.t.

“Wawancara dengan Adi (bukan nama sebenarnya) tanggal 15 Juli 2018," t.t.

“Wawancara dengan Cipto (bukan nama sebenarnya) tanggal 15 Juli 2018," t.t.

"Wawancara dengan Habib (bukan nama sebenarnya) tanggal 17 September 2018," t.t.

"Wawancara dengan Indra (bukan nama sebenarnya), tanggal 11 Agustus 2018," t.t.

"Wawancara dengan Rizki (bukan nama sebenarnya) pada tanggal 17 September 2018," t.t.

"Wawancara dengan Soleh (bukan nama sebenarnya) tanggal 11 Agustus 2018," t.t. 